\title{
max \\ Optimization of a Solution Treatment in the Al-Cu-Mg-Ag Alloy via a Microstructural Investigation
}

\author{
Hyeongsub So ${ }^{1,2}{ }^{\oplus}$, Jae-Hong Shin ${ }^{1}\left(\right.$, Leeseung Kang ${ }^{1}\left(\mathbb{D}\right.$, Chanuk Jeong ${ }^{3}$ and Kyou-Hyun Kim ${ }^{1, *}$ \\ 1 Korea-Russia Innovation Center, Korea Institute of Industrial Technology, Incheon 22004, Korea; \\ ksd8262@kitech.re.kr (H.S.); shinclusion@kitech.re.kr (J.-H.S.); leeseung@kitech.re.kr (L.K.) \\ 2 Department of Materials Science and Engineering, Korea University, Seoul 02841, Korea \\ 3 R\&D Center, Dongyang A.K Korea Co., Ltd., Sejong 30067, Korea; rndcuj@akglobal.net \\ * Correspondence: khkim1308@kitech.re.kr; Tel.: +82-32-458-5127
}

check for updates

Citation: So, H.; Shin, J.-H.; Kang, L.; Jeong, C.; Kim, K.-H. Optimization of a Solution Treatment in the Al-Cu-Mg-Ag Alloy via a Microstructural Investigation. Metals 2022, 12, 66. https://doi.org/ $10.3390 /$ met12010066

Academic Editor: Andrey Belyakov

Received: 30 November 2021

Accepted: 26 December 2021

Published: 29 December 2021

Publisher's Note: MDPI stays neutral with regard to jurisdictional claims in published maps and institutional affiliations.

Copyright: (C) 2021 by the authors. Licensee MDPI, Basel, Switzerland. This article is an open access article distributed under the terms and conditions of the Creative Commons Attribution (CC BY) license (https:// creativecommons.org/licenses/by/ $4.0 /)$.

\begin{abstract}
We investigated the effect of solution temperature $\left(T_{\text {sol. }}=440-530{ }^{\circ} \mathrm{C}\right)$ on the mechanical properties of the $\mathrm{Al}-3.4 \mathrm{Cu}-0.34 \mathrm{Mg}-0.3 \mathrm{Mn}-0.17 \mathrm{Ag}$ alloy, finding that the investigated $\mathrm{Al}$ alloy showed the highest mechanical strength of $\sigma_{\text {UTS }}=\sim 329 \mathrm{MPa}$ at a $T_{\text {sol. }}$ value of $470{ }^{\circ} \mathrm{C}$. The microstructural investigation demonstrates that the mechanical properties for different $T_{\text {sol. }}$ values stem from grain growth, precipitation hardening, and the formation of large particles at the grain boundaries. On the basis of $T_{\text {sol. }}=470{ }^{\circ} \mathrm{C}$, the effect of each microstructural evolution is significantly different on the mechanical properties. In this study, the relationships between the microstructural evolution and the mechanical properties were investigated with respect to different values of $T_{\text {sol. }}$.
\end{abstract}

Keywords: aluminum alloy; mechanical properties; microstructural evolution; solutionization

\section{Introduction}

High-strength $\mathrm{Al}-\mathrm{Cu}(5.0$ wt. $\%<\mathrm{Cu}<7.0$ wt.\%)-Mg-Ag-based alloys have been widely used owing to their excellent mechanical strength with the advantage of mass production [1-5]. To obtain high mechanical properties, $\mathrm{Al}-\mathrm{Cu}-\mathrm{Mg}$ alloys require posttreatment processes, such as a heat treatment and plastic working. Al 2xxx alloys are, in general, employed via several steps, including (1) casting, (2) homogenization, (3) hotrolling, (4) a solution treatment, (5) cold-rolling, and (6) artificial aging [5-8]. The conditions of each step are also optimized based on the compositions of the Al alloys.

Among several post-treatment processes, the solution treatment and artificial aging are of considerable importance to strengthen $\mathrm{Al}-\mathrm{Cu}-\mathrm{Mg}$ alloys by the formation of precipitates in the Al matrix [8-12]. The solution treatment process serves to induce the state of supersaturated solid solution (SSSS), which re-dissolves second phases into the matrix. Hence, the solution treatment temperature is determined based on minor elements added to Al. In Al-Cu-Mg-based alloys, the major second phases formed by minor elements are known to be intermetallic compounds of $\mathrm{Al}_{2} \mathrm{Cu}$ and $\mathrm{Al}-\mathrm{Cu}-\mathrm{Mn}-\mathrm{Fe}$ [13-17]. From the conventional binary phase diagram of $\mathrm{Al}-\mathrm{Cu}$, the melting temperature of the $\mathrm{Al}-\mathrm{Cu}$ $(5.0 \mathrm{wt} . \%<\mathrm{Cu}<7.0 \mathrm{wt} . \%)$ binary phase is approximately $550{ }^{\circ} \mathrm{C}$. Most high-strength Al$\mathrm{Cu}-\mathrm{Mg}$-based alloys are thus solution-treated at $\sim 530^{\circ} \mathrm{C}[2,3,7,10,18]$, while the maximum solubility of $\mathrm{Cu}$ to $\mathrm{Al}$ is only $5.57 \mathrm{wt} . \% \mathrm{Cu}$. Therefore, the solution treatment temperature is not high enough to re-dissolve the $\mathrm{Cu}$ minor elements into the $\mathrm{Al}$ matrix if the $\mathrm{Cu}$ content is higher than $5.57 \mathrm{wt} . \%$. An insufficient solution temperature induces the residual second phase particles in the grain boundaries of $\mathrm{Al}$, leading to the insufficient formation of precipitates in the $\mathrm{Al}$ matrix during the artificial aging process. Additionally, large particles remain in the grain boundaries due to the insufficient solution treatment temperature. It is well known that large particles in grain boundaries act as crack initiation sites, resulting in an increase in the brittleness $[6,19,20]$. 
On the other hand, the conventional solution treatment temperature of $\mathrm{Al} 2 \mathrm{xxx}$ alloys with $5.0 \mathrm{wt} . \%<\mathrm{Cu}<7.0 \mathrm{wt} . \%$ is high enough to induce the grain growth of $\mathrm{Al}$ grains. As shown in Figure 1, in the Al 2139 (Al-5.0Cu-0.50Mg) alloy, the grain growth is observed after a solution treatment at $530{ }^{\circ} \mathrm{C}$. The mechanical strength is inversely proportional to the grain size. The grain growth of the Al matrix, therefore, should be suppressed to achieve the maximum mechanical strength.
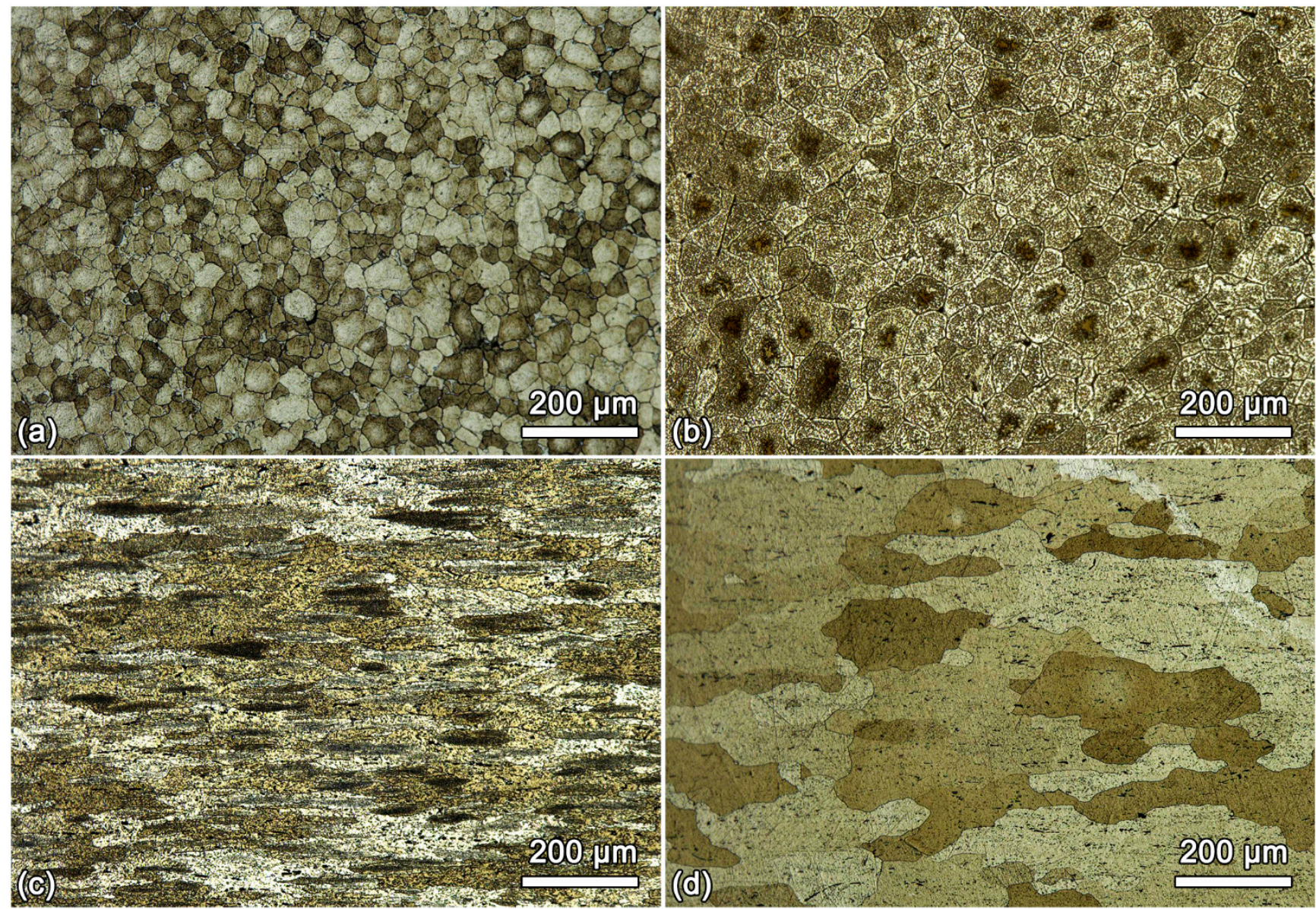

Figure 1. Microstructural investigations of each process of the $\mathrm{Al}-5.0 \mathrm{Cu}-0.50 \mathrm{Mg}-0.3 \mathrm{Mn}-0.17 \mathrm{Ag}$ commercial alloy: (a) as-cast, (b) homogenized, (c) hot-rolled, and (d) solutionized. This alloy is homogenized at $530{ }^{\circ} \mathrm{C}$ for $24 \mathrm{~h}$, solution treated at $530{ }^{\circ} \mathrm{C}$ for $3 \mathrm{~h}$, and aged at $160{ }^{\circ} \mathrm{C}$ for $24 \mathrm{~h}$ with the rolling processes.

Given the above considerations, the temperature range of the solution treatment for $\mathrm{Al}-\mathrm{Cu}-\mathrm{Mg}$-based (2xxx) alloys is very limited compared to those of other heat-treatable Al alloys, such as Al-Zn-Mg-based (7xxx) alloys. For example, the maximum solubility of Zn and $\mathrm{Mg}$ with regard to $\mathrm{Al}$ is $83.1 \mathrm{wt} . \%$ at $381{ }^{\circ} \mathrm{C}$ and $17.1 \mathrm{wt} \% \%$ at $450{ }^{\circ} \mathrm{C}$, respectively. The solution temperatures are far too low to induce grain growth during the solution treatment process, while the solubility can reach the maximum level [21-24]. Thus, 7xxx series Al alloys provide a wide range of solution temperatures to optimize the mechanical properties. This then motivates careful study to determine the optimum solution treatment temperature to achieve the maximum mechanical properties of $\mathrm{Al}-\mathrm{Cu}-\mathrm{Mg}$-based (2xxx) alloys.

In this study, we demonstrated the effect of the solution treatment temperature on the microstructures of the $\mathrm{Al}-\mathrm{Cu}-\mathrm{Mg}-\mathrm{Mn}-\mathrm{Ag}$ alloy resulting in a change of the mechanical properties. For the alloy design, we fabricated the $\mathrm{Al}-3.4 \mathrm{Cu}-0.34 \mathrm{Mg}-0.3 \mathrm{Mn}-0.17 \mathrm{Ag}$ alloy in order to investigate the wide temperature range for the solution treatment process. The maximum solid solution state can be achieved at $470{ }^{\circ} \mathrm{C}$, which is far below the melting temperature of $\mathrm{Al}$. Hence, the fabricated $\mathrm{Al}$ alloy samples underwent a solution treatment 
at $440{ }^{\circ} \mathrm{C}, 470{ }^{\circ} \mathrm{C}, 500{ }^{\circ} \mathrm{C}$, and $530{ }^{\circ} \mathrm{C}$. The solid solution state and its effect on the formation of precipitates in the Al matrix were mainly investigated at the solution temperatures of $440{ }^{\circ} \mathrm{C}$ and $470{ }^{\circ} \mathrm{C}$. For the other conditions, the effect of the grain growth was considered because the maximum solid solubility of $\mathrm{Cu}$ is above $470{ }^{\circ} \mathrm{C}$. Thus, this study provides a strategy by which to optimize the conditions of the solution treatment in order to develop a high-strength Al-Cu-Mg-based alloy.

\section{Experimental Procedures}

By using a gravity casting, the $\mathrm{Al}-3.4 \mathrm{Cu}-0.34 \mathrm{Mg}-0.3 \mathrm{Mn}-0.17 \mathrm{Ag}$ alloy was prepared with high-purity elements $(\mathrm{Al}, \mathrm{Cu}, \mathrm{Mg}$, and $\mathrm{Ag}$ ) and master alloys (Al-15 wt.\% Mn and Al-10 wt.\% Ti). All components were melted using an electric resistance furnace at $800{ }^{\circ} \mathrm{C}$, with the temperature held at this point for $30 \mathrm{~min}$. Thermo-mechanical processes were determined based on the conventional conditions as shown in Figure 2 [6,12,25-27]. The as-cast samples were homogenized at $530{ }^{\circ} \mathrm{C}$ for $24 \mathrm{~h}$ and cooled in air. The homogenized samples were then cut into thick plates $(120 \times 40 \times 30 \mathrm{~mm})$ for a rolling process. In the synthesized $\mathrm{Al}$ alloy, the maximum solubility of $\mathrm{Cu}$ in the $\mathrm{Al}$ matrix was achieved at around $550{ }^{\circ} \mathrm{C}$, while the melting temperature was $582^{\circ} \mathrm{C}$ with $3.375 \mathrm{wt} . \% \mathrm{Cu}$. Thus, the plates were solutionized at $440{ }^{\circ} \mathrm{C}, 470{ }^{\circ} \mathrm{C}, 500{ }^{\circ} \mathrm{C}$, and $530{ }^{\circ} \mathrm{C}$ for $3 \mathrm{~h}$ and quenched with water after the first hot rolling step. The solution temperatures used here are $80 \%, 85.5 \%, 90.9 \%$, and $96.3 \%$ of the melting temperature of Al. For the different solution treatment temperatures $\left(T_{\text {sol. }}\right)$, hereinafter, the specimens will be referred to correspondingly as sample I, sample II, sample III, and sample IV. Finally, the solutionized plates were cold-rolled under rolling reduction of $10 \%$ along the rolling direction and artificially aged in a muffle furnace at $160{ }^{\circ} \mathrm{C}$ for $24 \mathrm{~h}$ by a single-step aging treatment.

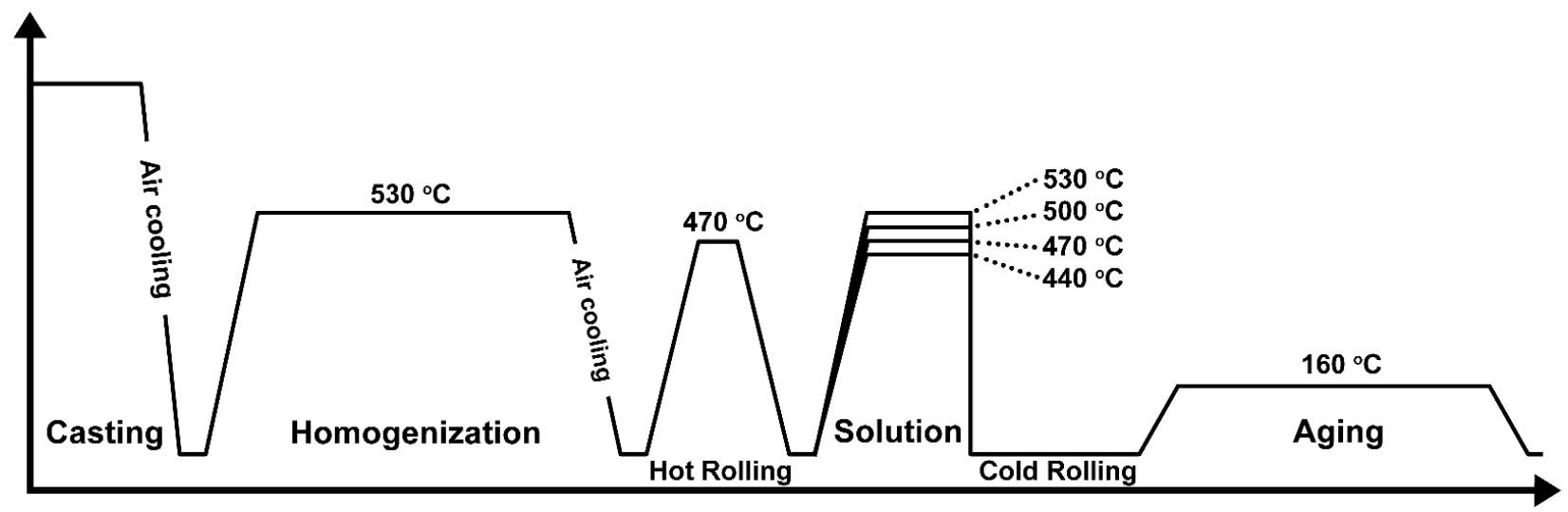

Figure 2. Schematic diagram of the applied tempering process.

Tensile tests were then done using ASTM E8 sub-size standard specimens with a total length, gage length, width, and thickness of $100 \mathrm{~mm}, 25 \mathrm{~mm}, 6 \mathrm{~mm}$, and $2.5 \mathrm{~mm}$, respectively [28]. The tensile properties were then measured more than ten times for each specimen using a precision universal testing machine (AGX-V, SHIMADZU, Kyoto, Japan) with a strain rate of $2 \mathrm{~mm} / \mathrm{min}$ under ambient temperature conditions. The microstructures of the Al alloys were investigated from the macroscopic scale (few tens $\mu \mathrm{m}$ to $\sim$ hundreds $\mu \mathrm{m}$ ) to the microscopic scale (few tens $\mu \mathrm{m} \sim \mathrm{nm}$ ). For the macroscopic observations using an optical microscope (OM), the specimens were mechanically mirror-polished and chemically etched with a proper etchant $\left(95.5 \%\right.$ water, $\left.2 \% \mathrm{HNO}_{3}, 1.5 \% \mathrm{HCl}, 1 \% \mathrm{HF}\right)$. Details of the chemical composition and overall phase identification were determined with a field emission scanning electron microscope (FE-SEM, JSM-7100F, JEOL, Kyoto, Japan) and by an energy dispersive X-ray microanalysis (EDSX, X-max, Oxford, UK). For the microscopic structural investigation, the specimens were mechanically polished down to $\sim 10 \mu \mathrm{m}$ and Ar-ion milled at an incident angle of $6^{\circ}$ with an accelerating voltage of $3.0 \mathrm{keV}$ to ensure electron transparency. The ultra-thin specimens were then investigated 
using field-emission transmission electron microscopy (FE-TEM, JEM-ARM200F, JEOL Ltd., Tokyo, Japan) at room temperature.

\section{Results and Discussion}

Figure 3 shows the tensile properties of $\mathrm{Al}-3.4 \mathrm{Cu}-0.34 \mathrm{Mg}-0.3 \mathrm{Mn}-0.17 \mathrm{Ag}$ for different values of $T_{\text {sol. }}$. The mechanical properties of sample I were determined to be $\sigma_{\mathrm{y}}=261 \pm 4.25 \mathrm{MPa}$ and $\sigma_{\mathrm{UTS}}=329 \pm 8.17 \mathrm{MPa}$ with an $\varepsilon$ (elongation) rate of 13.1 $( \pm 0.29) \%$. As shown in Figure 3, the tensile stress gradually increased as $T_{\text {sol. }}$ increased. The maximum tensile stress was achieved when $T_{\text {sol. }}$ was $470{ }^{\circ} \mathrm{C}$ (sample II), while the elongation was slightly reduced to $\sim 12.1( \pm 0.49) \%$. The tensile stress was then degraded when $T_{\text {sol. }}$ exceeded $470{ }^{\circ} \mathrm{C}$. The tensile stresses were found to be $279 \pm 7.09 \mathrm{MPa}\left(\sigma_{\mathrm{y}}\right)$ and $346 \pm 9.87 \mathrm{MPa}\left(\sigma_{\text {UTS }}\right)$ for sample III and $\sim 258 \pm 8.94 \mathrm{MPa}\left(\sigma_{\mathrm{y}}\right)$ and $\sim 326 \pm 7.08 \mathrm{MPa}$ $\left(\sigma_{\text {UTS }}\right)$ for sample IV. In contrast, the elongation outcomes increased sharply as follows: $15.2( \pm 0.56) \%$ (sample III) $\rightarrow 16.7( \pm 0.68) \%$ (sample IV).

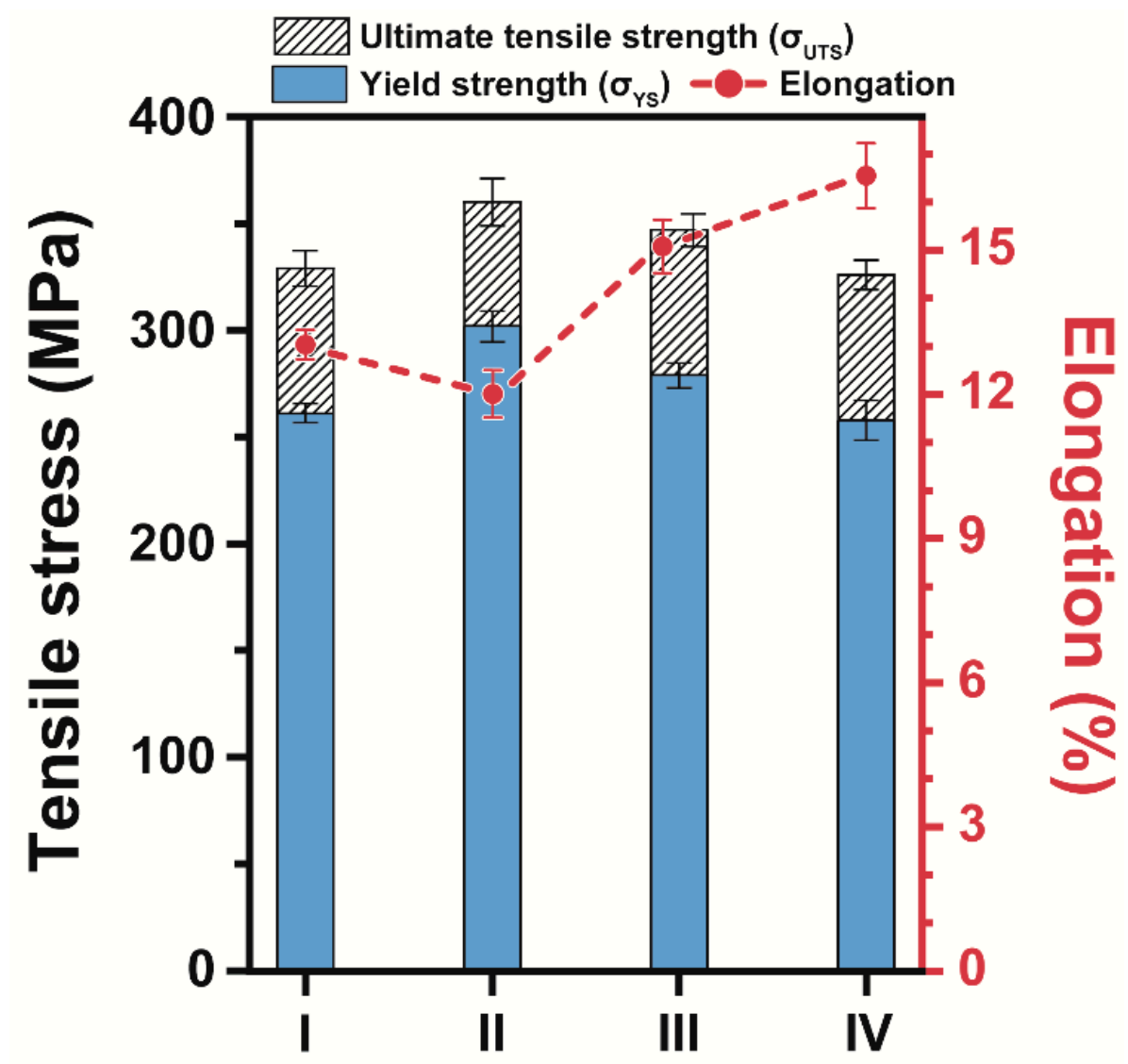

Figure 3. Tensile properties of the synthesized alloys with respect to the various values of $T_{\text {sol. }}$.

Figure 4 shows typical OM images of samples I-IV observed along the rolling direction (RD) of the cold-rolled (CR) specimens. In order to observe the change in the grain size, the OM images were recorded from approximately 30 different regions of each sample and averaged, as presented in Figure 4e. Figure 4e shows that the average grain sizes gradually increased by $\sim 98( \pm 25.7) \mu \mathrm{m}$ (sample I) $\rightarrow \sim 131( \pm 25.0) \mu \mathrm{m}$ (sample II) $\rightarrow \sim 181( \pm 34.6) \mu \mathrm{m}$ (sample III) $\rightarrow \sim 203( \pm 46.9) \mu \mathrm{m}$ (sample IV) as $T_{\text {sol. }}$ increased. It can be clearly observed that the grain size of $\mathrm{Al}$ was highly sensitive to $T_{\text {sol. }}$. In addition, the investigated range of $T_{\text {sol. from }} 440{ }^{\circ} \mathrm{C}$ to $530{ }^{\circ} \mathrm{C}$ was sufficient to induce grain growth at the $\mathrm{Al}$ matrix of $\mathrm{Al}-3.4 \mathrm{Cu}-0.34 \mathrm{Mg}-0.3 \mathrm{Mn}-0.17 \mathrm{Ag}$. In general, the grain size is inversely proportional to the mechanical strength. As shown in Figure 4, however, the tensile stress of sample II was enhanced compared to that of sample I, while the average grain size of sample II was much larger than the grain size of sample I. In contrast, the tensile stresses of sample III and IV 
decreased drastically compared to that of sample II, identical to the variations of the grain size shown in Figure 4. A discussion of these findings with regard to the microstructural changes is provided later in the paper.
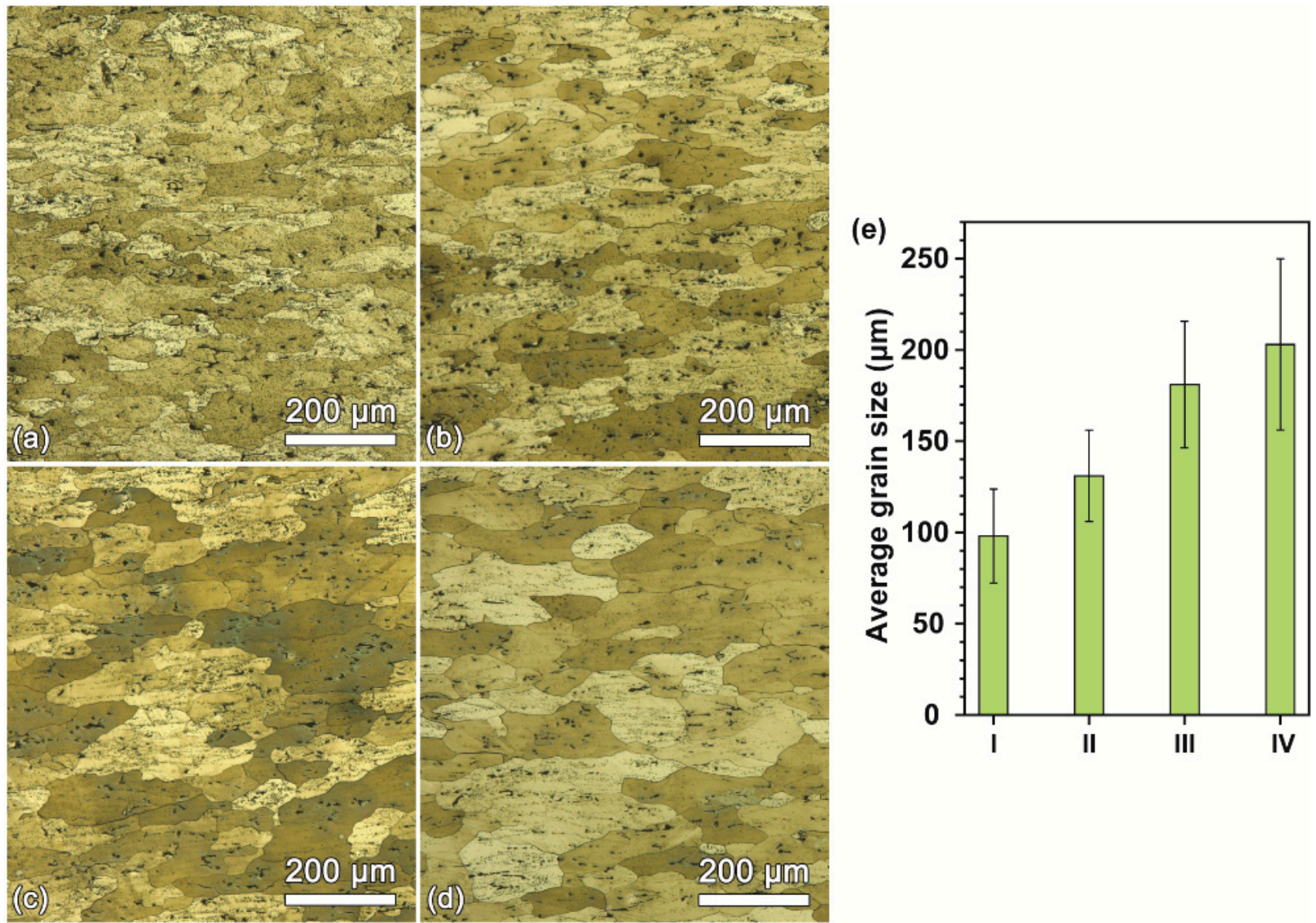

Figure 4. OM microstructures of (a) sample I, (b) sample II, (c) sample III, and (d) sample IV. The average grain sizes are provided in (e) with the error bar.

Figure 5 shows backscattered electron micrographs (BSE) of the synthesized alloys recorded along the rolling direction (RD). Two different phases were clearly observed in the grain boundary regions, as indicated by the arrows I and II in Figure 5. A chemical analysis then revealed that the corresponding particles, which formed in the grain boundaries, are the $\mathrm{Al}-\mathrm{Cu}-\mathrm{Mn}-\mathrm{Fe}$ (yellow arrow) and $\mathrm{Al}_{2} \mathrm{Cu}$ (black arrow) phases, which are in general observed in $\mathrm{Al}-\mathrm{Cu}-\mathrm{Mg}-\mathrm{Ag}$ alloys [13-17]. During the solution treatment process, solute atoms were dissolved into the $\mathrm{Al}$ matrix to generate SSSS, which resulted in the formation of strengthening phases in the $\mathrm{Al}$ matrix after the artificial aging process. Macroscopically, the average particle sizes of $\mathrm{Al}-\mathrm{Cu}-\mathrm{Mn}-\mathrm{Fe}$ and $\mathrm{Al}_{2} \mathrm{Cu}$ simultaneously decreased by $\sim 23.5 \pm 6.38 \mu \mathrm{m}$ (sample I) $\rightarrow \sim 18.3 \pm 6.64 \mu \mathrm{m}$ (sample II) $\rightarrow \sim 12.36 \pm 3.94 \mu \mathrm{m}$ (sample III) $\rightarrow \sim 6.76 \pm 1.18 \mu \mathrm{m}$ (sample IV) as $T_{\text {sol. }}$ increased. In addition to the decrease in the particle size, Figure 6 shows the changes of the area fractions of $\mathrm{Al}-\mathrm{Cu}-\mathrm{Mn}-\mathrm{Fe}$ and $\mathrm{Al}_{2} \mathrm{Cu}$ particles with respect to $T_{\text {sol. }}$. The average area fractions of $\mathrm{Al}_{2} \mathrm{Cu}$ particles in each alloy were determined to be by $1.10,1.09,0.89$, and $0.49 \%$. Additionally, the area fractions of $\mathrm{Al}-\mathrm{Cu}-\mathrm{Mn}-\mathrm{Fe}$ particles were found to be 3.53, 1.51, 0.52, and $0.25 \%$. Regarding the solubility of the constituent elements in the Al matrix, Table 1 shows that the major element of $\mathrm{Cu}$ gradually increased as $T_{\text {sol. }}$ increased. On the other hand, the increased level of $\mathrm{Cu}$ elements in the $\mathrm{Al}$ matrix facilitated the formation of major hardening precipitates of $\mathrm{Al}_{2} \mathrm{Cu}$ after the artificial aging process. The tensile stress of synthesized alloys, however, reached its maximum at a $T_{\text {sol. }}$ value of $470{ }^{\circ} \mathrm{C}$, while the minimum particle size and the maximum 
$\mathrm{Cu}$ solubility were both achieved at a $T_{\text {sol. }}$ value of $530{ }^{\circ} \mathrm{C}$. Moreover, the mechanical strength gradually decreased as $T_{\text {sol. }}$ exceeded $470{ }^{\circ} \mathrm{C}$, while the elongation increased drastically. For heat-treatable $\mathrm{Al}$ alloys, the formation of hardening phases in the $\mathrm{Al}$ matrix is mostly subject to the mechanical properties. A nanoscopic structure investigation using TEM was therefore conducted in order to investigate the behavior of the formation of the hardening phases.

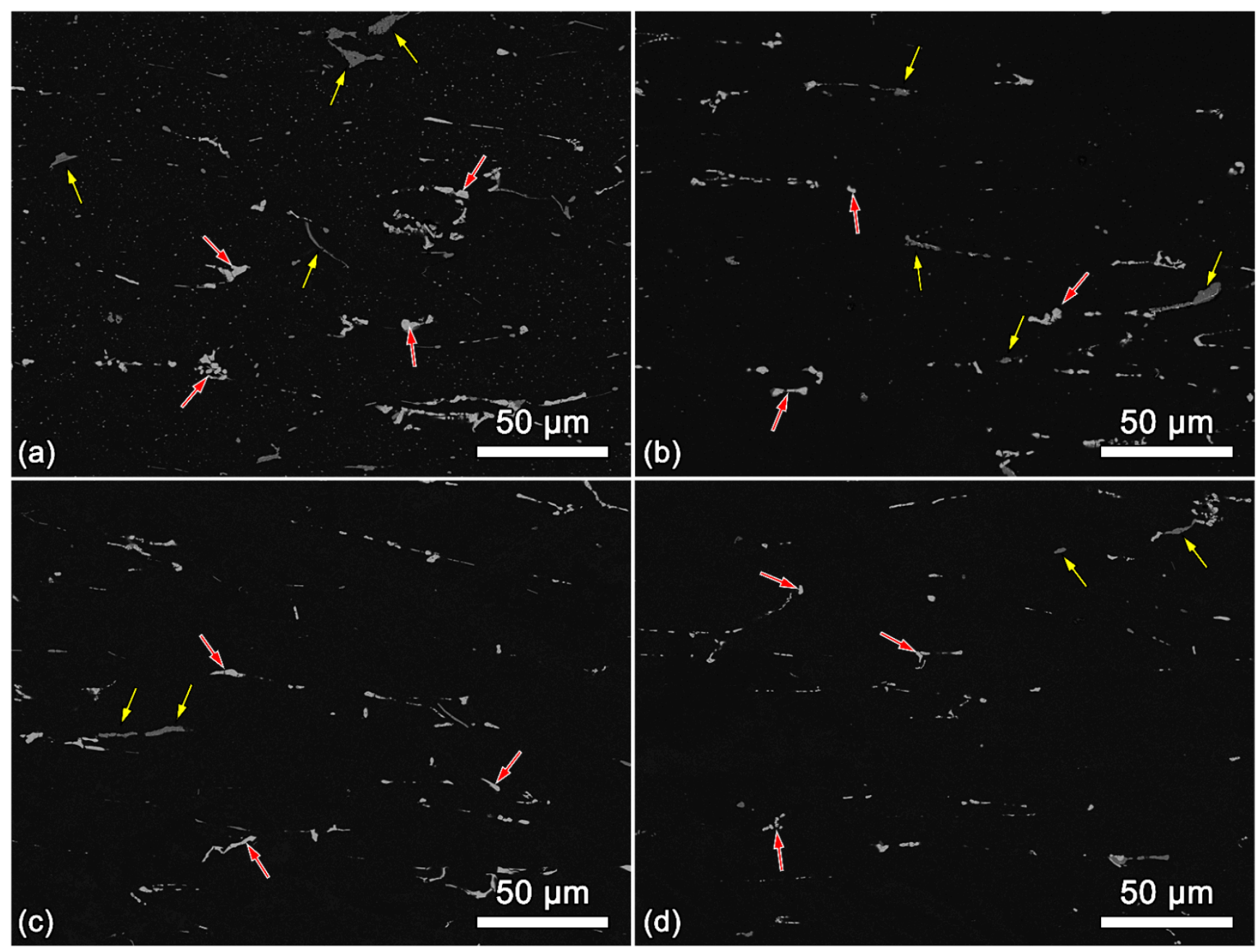

Figure 5. Backscattered electron microscopy recorded from (a) sample I, (b) sample II, (c) sample III, and (d) sample IV. Two coarse phases are pointed with yellow arrow (Al-Cu-Mn-Fe) and red arrow $\left(\mathrm{Al}_{2} \mathrm{Cu}\right)$.

Table 1. Chemical composition (at.\%) in the $\mathrm{Al}$ matrix of the aged $\mathrm{Al}-\mathrm{Cu}-\mathrm{Mg}-\mathrm{Mn}-\mathrm{Ag}$ alloys.

\begin{tabular}{cccccc}
\hline Alloys & $\mathbf{C u}$ & $\mathbf{M g}$ & $\mathbf{M n}$ & $\mathbf{A g}$ & Al \\
\hline Sample I & $2.71( \pm 0.08)$ & $0.33( \pm 0.08)$ & $0.18( \pm 0.01)$ & $0.23( \pm 0.02)$ & Bal. \\
Sample II & $3.32( \pm 0.24)$ & $0.27( \pm 0.09)$ & $0.29( \pm 0.03)$ & $0.09( \pm 0.02)$ & Bal. \\
Sample III & $3.45( \pm 0.05)$ & $0.29( \pm 0.05)$ & $0.35( \pm 0.04)$ & $0.10( \pm 0.01)$ & Bal. \\
Sample IV & $3.60(( \pm 0.23)$ & $0.30( \pm 0.08)$ & $0.34( \pm 0.02)$ & $0.06( \pm 0.02)$ & Bal. \\
\hline
\end{tabular}




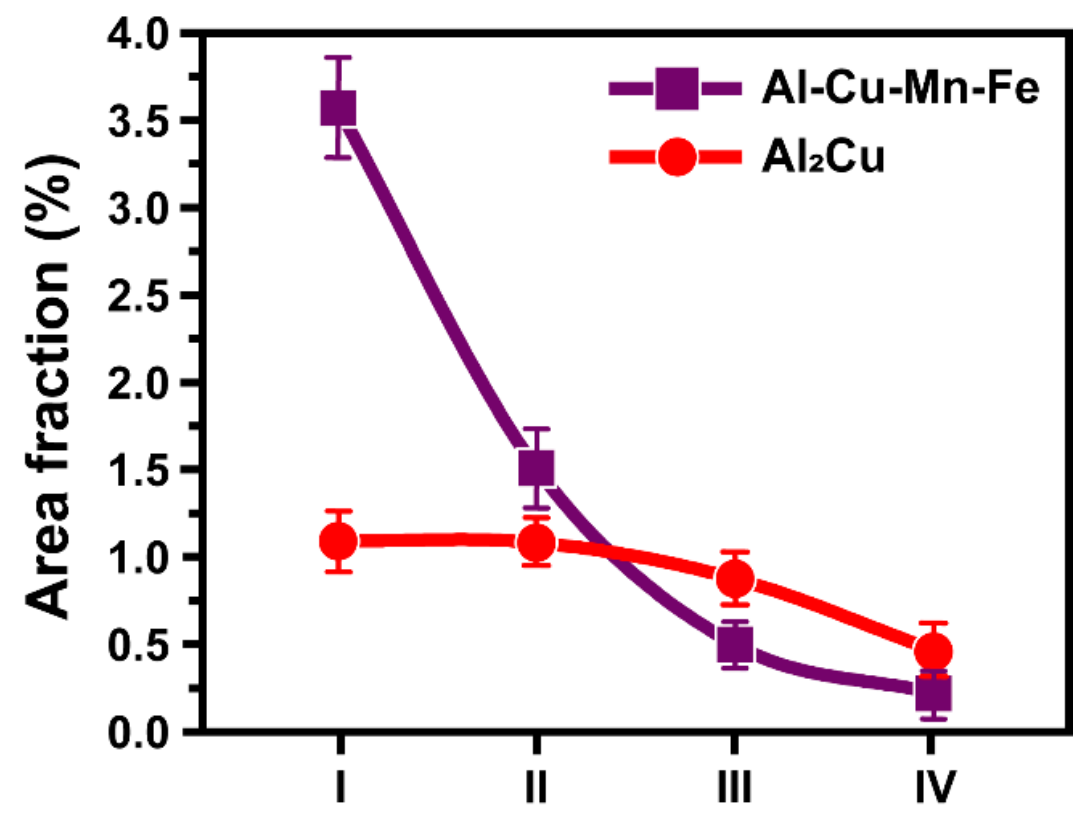

Figure 6. Area fractions of second phases in the synthesized $\mathrm{Al}$ alloys.

Figure 7 presents typical TEM micrographs of samples I-IV recorded under medium magnification with the corresponding spot electron diffraction (ED) patterns. TEM investigations were performed in all cases along the zone axis of $\{110\}_{\mathrm{Al}}$, which is the optimum direction at which to investigate the hardening phases of $\theta^{\prime}$ and $\Omega$. From earlier reports, it is well known that the $\theta^{\prime}$ and $\Omega$ phase are respectively lied on $\{002\}$ and $\{111\}[2,7,9,29,30]$. Figure 7e shows the number density of precipitates calculated from each specimen. For sample I, the number density was about $89.49( \pm 27.25) / \mu \mathrm{m}^{2}$. This value was similar to that of sample II $\left(114.25( \pm 44.90) / \mu \mathrm{m}^{2}\right)$, though $T_{\text {sol. }}$ increased. The formation of hardening phases, however, was drastically enhanced in sample II. The calculated number densities of the precipitates were $173.91( \pm 37.19) / \mu \mathrm{m}^{2}$ and $358.43( \pm 63.52) / \mu \mathrm{m}^{2}$ for sample III and sample IV, respectively. The drastic increase in the hardening phases could also be confirmed in the spot ED patterns. As shown in the inset of Figure 7a,b, samples I and II consisted of Al Bragg spots for the zone axis of $\{110\}_{\mathrm{Al}}$ without any evidence of hardening phases in the Al matrix. In contrast, coherently formed hardening phases were well-observed as streaks along the $\{110\}_{\mathrm{Al}}$ and $\{002\}_{\mathrm{Al}}$ directions in the spot ED patterns of samples III and IV (Figure 7c,d). On the other hand, the variations in the number densities were nearly identical to the content of $\mathrm{Cu}$ solute elements in the $\mathrm{Al}$ matrix, as shown in Figure 7e. Interestingly, the number density of the hardening phases was highly sensitive to the $\mathrm{Cu}$ solute atoms when $T_{\text {sol. }}$ exceeded $470{ }^{\circ} \mathrm{C}$, where $3.4 \mathrm{wt} . \% \mathrm{Cu}$ was entirely solutionized in the binary phase diagram of $\mathrm{Al}-\mathrm{Cu}$. The amount of $\mathrm{Cu}$ solute (at.\%), presented in Table 1, increased by $\sim 125 \%$ from sample I to sample II. In contrast, the increment of Cu solute was only a few percent when the $T_{\text {sol. }}$ was greater than $470{ }^{\circ} \mathrm{C}$. This suggests that $T_{\text {sol. }}$ was not the only consideration to achieve the maximum solubility of major solute elements in order to facilitate the formation of a hardening phase. 


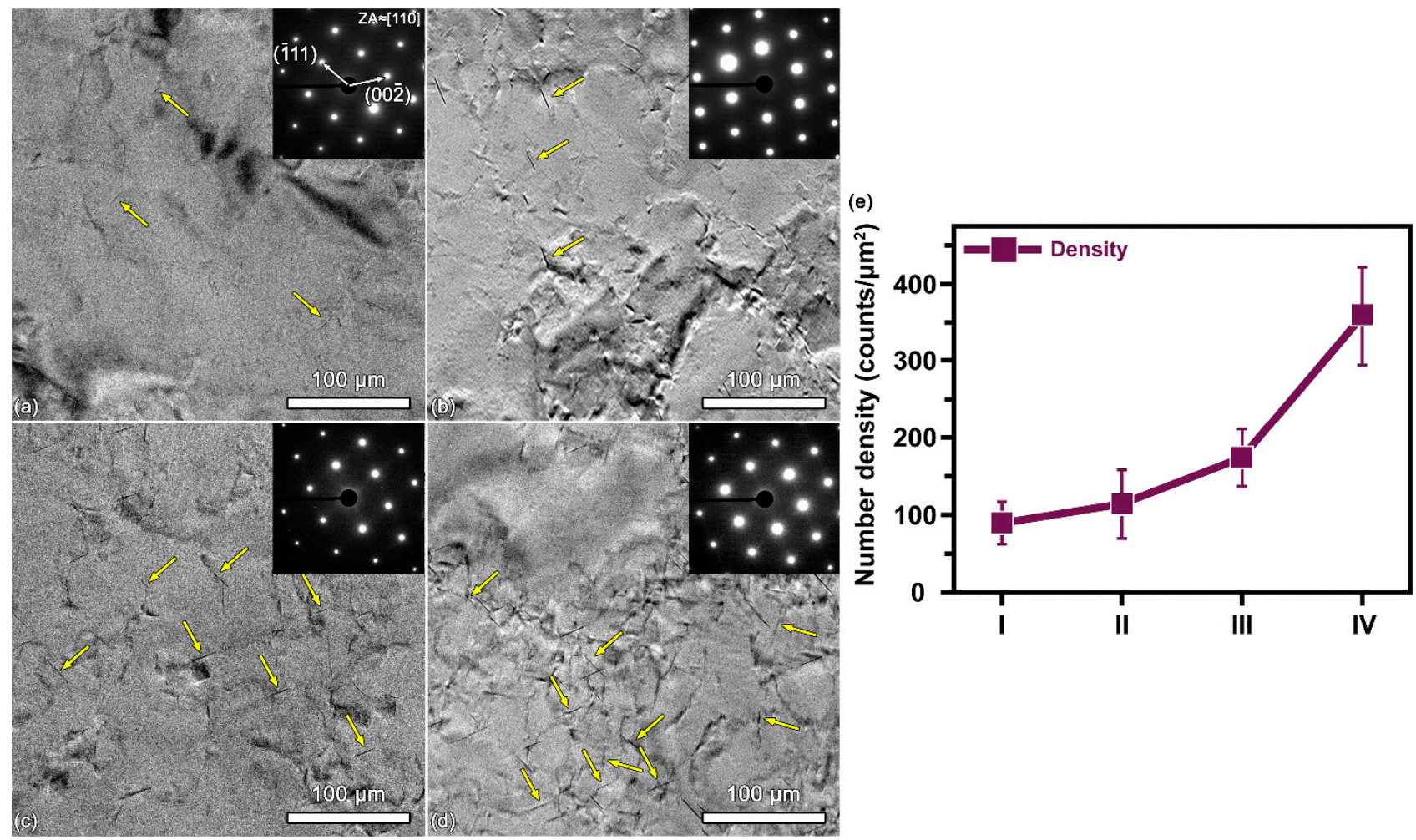

Figure 7. (a-d) Medium-magnification BF images and corresponding electron diffraction results recorded at the $\{110\}_{\mathrm{Al}}$ zone axis: (a) sample I, (b) sample II, (c) sample III, (d) sample IV, and (e) number density of hardening phases $\left(\theta^{\prime}\right.$ and $\Omega$ ) with respect to $T_{\text {sol. }}$.

Considering the above findings, $T_{\text {sol. }}$ affects the mechanical properties of the Al$\mathrm{Cu}-\mathrm{Mg}-\mathrm{Ag}$ alloy in terms of three microstructural aspects. First, the tensile stress was mainly determined by the number density of the hardening precipitates $\left(\theta^{\prime}\right.$ and $\Omega$ ) from $440{ }^{\circ} \mathrm{C}$ to $470{ }^{\circ} \mathrm{C}$. For this $T_{\text {sol. }}$ range, the $\mathrm{OM}$ images indicate that the $\mathrm{Al}$ grains grew significantly by $\sim 140 \%(98 \mu \mathrm{m} \rightarrow 131 \mu \mathrm{m})$. Nevertheless, the tensile stress was improved from $\sigma_{\text {UTS }}=329 \mathrm{MPa}$ to $\sigma_{\text {UTS }}=360 \mathrm{MPa}$. The binary phase diagram of Al-Cu indicated that $3.4 \mathrm{wt} . \% \mathrm{Cu}$ had maximum solubility above a $T_{\text {sol. }}$ value of approximately $470{ }^{\circ} \mathrm{C}$ as proven by a chemical analysis (Table 1 ). In consequence, an increase in the $\mathrm{Cu}$ solubility level in $\mathrm{Al}$ (Table 1 ) facilitated the formation of hardening precipitates $\left(\theta^{\prime}\right.$ and $\Omega$ ) in the $\mathrm{Al}$ matrix, which improved the tensile stress.

Second, the mechanical properties were affected by the grain growth at $T_{\text {sol. }}$ of $470{ }^{\circ} \mathrm{C}$. At the $T_{\text {sol. }}$. value of $\sim 500-530^{\circ} \mathrm{C}$, the $\mathrm{Cu}$ solute in the $\mathrm{Al}$ matrix was mostly saturated. The number density of the hardening precipitates reached its maximum of 358.43 counts $/ \mu \mathrm{m}^{2}$ at $T_{\text {sol. }}$ of $530{ }^{\circ} \mathrm{C}$, while the tensile stresses were gradually reduced to $326 \mathrm{MPa}$. This is considered to be a result of the growth of $\mathrm{Al}$ grains. The $\mathrm{Al}$ grain size increased to $203 \mu \mathrm{m}$ at $530{ }^{\circ} \mathrm{C}$, while the initial $\mathrm{Al}$ grain size was $98 \mu \mathrm{m}$. That is, the grain size of $\mathrm{Al}$ mainly determined the mechanical properties of the $\mathrm{Al}-\mathrm{Cu}-\mathrm{Mg}-\mathrm{Ag}$ alloy once the $\mathrm{Cu}$ solute was maximized.

Finally, the elongation of the investigated alloys was primarily determined by the large particles that formed at the grain boundaries. As shown in Figure 5, large particles formed at the grain boundaries of the $\mathrm{Al}-3.4 \mathrm{Cu}-0.34 \mathrm{Mg}-0.3 \mathrm{Mn}-0.17 \mathrm{Ag}$ alloy. The large particles were then finely distributed as $T_{\text {sol. }}$ increased. The area fractions of the large particles (Al-Cu-Mn-Fe and $\mathrm{Al}_{2} \mathrm{Cu}$ ) abruptly decreased and reached their minimum value at the highest $T_{\text {sol. }}$ level of $530^{\circ} \mathrm{C}$. In general, large particles are known to act as crack initiation and development sites $[6,20]$. Consequently, a decrease in the number of large particles resulted in an increase in the elongation in the $\mathrm{Al}-3.4 \mathrm{Cu}-0.34 \mathrm{Mg}-0.3 \mathrm{Mn}-0.17 \mathrm{Ag}$ alloy. 


\section{Conclusions}

We investigated the microstructural evolution of the $\mathrm{Al}-3.4 \mathrm{Cu}-0.34 \mathrm{Mg}-0.3 \mathrm{Mn}-0.17 \mathrm{Ag}$ alloy with respect to a wide range of $T_{\text {sol. }}$ values. Interestingly, in this study, the mechanical properties of the $\mathrm{Al}-\mathrm{Cu}-\mathrm{Mg}-\mathrm{Ag}$ alloy were determined by several factors according to the solution temperature $\left(T_{\text {sol. }}\right)$. The used $T_{\text {sol. }}$ could then be divided into three ranges based on the $\mathrm{Cu}$ solid solution: (1) an insufficient solution temperature range $\left(T_{\text {sol. }}<470{ }^{\circ} \mathrm{C}\right),(2)$ a sufficient solution temperature range $\left(T_{\text {sol. }} \approx 470{ }^{\circ} \mathrm{C}\right)$, and $(3)$ a high solution temperature range $\left(T_{\text {sol. }}>470{ }^{\circ} \mathrm{C}\right)$. For the first temperature range of $440{ }^{\circ} \mathrm{C}<T_{\text {sol. }}<470{ }^{\circ} \mathrm{C}$, the amount of $\mathrm{Cu}$ solute increased in the $\mathrm{Al}$ matrix to facilitate the formation of hardened nanoprecipitates $\left(\theta^{\prime}\right.$ and $\Omega$ ). This then resulted in an improvement of the tensile stress while grain growth was observed. For the next temperature range of $T_{\text {sol. }}>470{ }^{\circ} \mathrm{C}$, the number density of hardening precipitates was maximized. Nevertheless, the grain growth acted as a dominant factor to lower the tensile stress of the synthesized alloys, unlike in the first temperature range of $440{ }^{\circ} \mathrm{C}<T_{\text {sol. }}<470{ }^{\circ} \mathrm{C}$. On the other hand, the decrease of the volume fraction of the large particles helped to improve the ductility of the synthesized alloys. Based on the above, therefore, the solution temperatures should be properly controlled to (1) optimize the microstructural evolutions of the grain growth of $\mathrm{Al}$, to (2) decrease the number of large particles, which form at the grain boundaries, and to (3) facilitate the hardening of precipitates of $\mathrm{Al}_{2} \mathrm{Cu}$ in order to optimize the mechanical properties of $\mathrm{Al}-\mathrm{Cu}-\mathrm{Mg}-\mathrm{Ag}$ alloys.

Author Contributions: Conceptualization, H.S.; investigation, H.S. and C.J.; data curation, H.S.; writing-original draft preparation, H.S.; writing—review and editing, J.-H.S., L.K. and K.-H.K.; project administration, K.-H.K.; resources, J.-H.S.; supervision, L.K.; funding acquisition, K.-H.K. All authors have read and agreed to the published version of the manuscript.

Funding: This research was financially supported by the Institute of Civil Military Technology Cooperation funded by the Defense Acquisition Program Administration and by the Ministry of Trade, Industry, and Energy of the Korean government under Grant No. UM21308RD3. This study was also equally supported by the R\&D program from the Korea Institute of Industrial Technology.

Institutional Review Board Statement: Not applicable.

Informed Consent Statement: Not applicable.

Data Availability Statement: The raw/processed data required to reproduce these findings cannot be shared at this time as the data also forms part of an ongoing study.

Conflicts of Interest: The authors declare no conflict of interest.

\section{References}

1. Xiao, D.H.; Wang, J.N.; Ding, D.Y.; Chen, S.P. Effect of Cu content on the mechanical properties of an Al-Cu-Mg-Ag alloy. J. Alloys Compd. 2002, 343, 77-81. [CrossRef]

2. Polmear, I.J.; Pons, G.; Barbaux, Y.; Octor, H.; Sanchez, C.; Morton, A.J.; Borbidge, W.E.; Rogers, S. After Concorde: Evaluation of creep resistant Al-Cu-Mg-Ag alloys. Mater. Sci. Technol. 1999, 15, 861-868. [CrossRef]

3. Xiao, D.H.; Wang, J.N.; Ding, D.Y.; Yang, H.L. Effect of rare earth Ce addition on the microstructure and mechanical properties of an Al-Cu-Mg-Ag alloy. J. Alloys Compd. 2003, 352, 84-88. [CrossRef]

4. Gazizov, M.; Teleshov, V.; Zakharov, V.; Kaibyshev, R. Solidification behaviour and the effects of homogenisation on the structure of an Al-Cu-Mg-Ag-Sc alloy. J. Alloys Compd. 2011, 509, 9497-9507. [CrossRef]

5. Zuiko, I.; Kaibyshev, R. Effect of plastic deformation on the ageing behaviour of an $\mathrm{Al}-\mathrm{Cu}-\mathrm{Mg}$ alloy with a high $\mathrm{Cu} / \mathrm{Mg}$ ratio. Mater. Sci. Eng. A 2018, 737, 401-412. [CrossRef]

6. So, H.; Won, S.J.; Park, J.; Oh, S.J.; Kang, L.; Kim, K.H. Mechanical properties and microstructural evolution in Al-Cu-Mg-Ag alloy with a $\mathrm{Cu}_{\mathrm{x}} \mathrm{Mg}_{\mathrm{x} / 10}$ content. Mater. Sci. Eng. A 2021, 824, 141573. [CrossRef]

7. Lumley, R.N.; Morton, A.J.; Polmear, I.J. Enhanced creep performance in an Al-Cu-Mg-Ag alloy through underageing. Acta Mater. 2002, 50, 3597-3608. [CrossRef]

8. Marceau, R.K.W.; Sha, G.; Ferragut, R.; Dupasquier, A.; Ringer, S.P. Solute clustering in Al-Cu-Mg alloys during the early stages of elevated temperature ageing. Acta Mater. 2010, 58, 4923-4939. [CrossRef]

9. Gable, B.M.; Shiflet, G.J.; Starke, E.A. Alloy development for the enhanced stability of Omega precipitates in Al-Cu-Mg-Ag alloys. Metall. Mater. Trans. A 2006, 37A, 1091-1105. [CrossRef] 
10. Liu, X.Y.; Pan, Q.L.; Lu, Z.L.; Cao, S.F.; He, Y.B.; Li, W.B. Effects of solution treatment on the microstructure and mechanical properties of Al-Cu-Mg-Ag alloy. Mater. Des. 2010, 31, 4392-4397. [CrossRef]

11. Ibrahim, M.F.; Samuel, A.M.; Samuel, F.H. A preliminary study on optimizing the heat treatment of high strength Al-Cu-Mg-Zn alloys. Mater. Des. 2014, 57, 342-350. [CrossRef]

12. Zamani, M.; Toschi, S.; Morri, A.; Ceschini, L.; Seifeddine, S. Optimisation of heat treatment of Al-Cu-(Mg-Ag) cast alloys. J. Therm. Anal. Calorim. 2020, 139, 3427-3440. [CrossRef]

13. Wang, S.C.; Starink, M.J. Precipitates and intermetallic phases in precipitation hardening Al-Cu-Mg-(Li) based alloys. Int. Mater. Rev. 2005, 50, 193-215. [CrossRef]

14. Ilevbare, G.O.; Scully, J.R. Oxygen reduction reaction kinetics on chromate conversion coated Al-Cu, $\mathrm{Al}-\mathrm{Cu}-\mathrm{Mg}$, and Al-Cu-Mn-Fe intermetallic compounds. J. Electrochem. Soc. 2001, 148, B196-B207. [CrossRef]

15. Li, J.C.; Birbilis, N.; Buchheit, R.G. Electrochemical assessment of interfacial characteristics of intermetallic phases present in aluminium alloy 2024-T3. Corros. Sci. 2015, 101, 155-164. [CrossRef]

16. Boag, A.P.; McCulloch, D.G.; Jamieson, D.N.; Hearne, S.M.; Hughes, A.E.; Ryan, C.G.; Toh, S.K. Combined nuclear microprobe and TEM study of corrosion pit nucleation by intermetallics in aerospace aluminium alloys. Nucl. Instrum. Methods Phys. Res. B 2005, 231, 457-462. [CrossRef]

17. Alba-Galvin, J.J.; Gonzalez-Rovira, L.; Bethencourt, M.; Botana, F.J.; Sanchez-Amaya, J.M. Influence of Aerospace Standard Surface Pretreatment on the Intermetallic Phases and CeCC of 2024-T3 Al-Cu Alloy. Metals 2019, 9, 320. [CrossRef]

18. Bai, S.; Liu, Z.Y.; Gu, Y.X.; Zhou, X.W.; Zeng, S.M. Microstructures and fatigue fracture behavior of an Al-Cu-Mg-Ag alloy with a low $\mathrm{Cu} / \mathrm{Mg}$ ratio. Mater. Sci. Eng. A 2011, 530, 473-480. [CrossRef]

19. Park, M.J.; So, H.; Kang, L.S.; Byeon, J.W.; Kim, K.H. The relation between mechanical properties and microstructural evolution induced by Sc microalloying in Al-20Zn-3Cu alloy. J. Alloys Compd. 2021, 889, 161719-161725. [CrossRef]

20. Zhou, Q.; Wang, J.; Misra, A.; Huang, P.; Wang, F.; Xu, K.W. Atomistic study of fundamental character and motion of dislocations in intermetallic $\mathrm{Al}_{2} \mathrm{Cu}$. Int. J. Plast. 2016, 87, 100-113. [CrossRef]

21. Rafi, H.K.; Ram, G.D.J.; Phanikumar, G.; Rao, K.P. Microstructure and tensile properties of friction welded aluminum alloy AA7075-T6. Mater. Des. 2010, 31, 2375-2380. [CrossRef]

22. Tian, S.K.; Li, J.Y.; Zhang, J.L.; Zhumabieke, W.; Lv, D. Effect of Zr and Sc on microstructure and properties of 7136 aluminum alloy. J. Mater. Res. Technol. 2019, 8, 4130-4140. [CrossRef]

23. Xu, D.K.; Rometsch, P.A.; Birbilis, N. Improved solution treatment for an as-rolled Al-Zn-Mg-Cu alloy. Part II. Microstructure and mechanical properties. Mater. Sci. Eng. A 2012, 534, 244-252. [CrossRef]

24. Ghiaasiaan, R.; Zeng, X.C.; Shankar, S. Controlled Diffusion Solidification (CDS) of Al-Zn-Mg-Cu (7050): Microstructure, heat treatment and mechanical properties. Mater. Sci. Eng. A 2014, 594, 260-277. [CrossRef]

25. Liu, X.Y.; Pan, Q.L.; Fan, X.; He, Y.B.; Li, W.B.; Liang, W.J. Microstructural evolution of Al-Cu-Mg-Ag alloy during homogenization. J. Alloys Compd. 2009, 484, 790-794. [CrossRef]

26. Cho, A.; Bes, B. Damage tolerance capability of an Al-Cu-Mg-Ag alloy(2139). Mater. Sci. Forum 2006, 519-521, 603-608. [CrossRef]

27. Zuiko, I.S.; Kaibyshev, R. Ageing response of cold-rolled Al-Cu-Mg alloy. Mater. Sci. Eng. A 2020, 781, 139148. [CrossRef]

28. ASTM, E. Standard Test Methods for Tension Testing of Metallic Materials; 2001. Available online: https://www.astm.org/e000801.html (accessed on 29 November 2021).

29. Hutchinson, C.R.; Fan, X.; Pennycook, S.J.; Shiflet, G.J. On the origin of the high coarsening resistance of Omega plates in Al-Cu-Mg-Ag alloys. Acta Mater. 2001, 49, 2827-2841. [CrossRef]

30. Ringer, S.P.; Yeung, W.; Muddle, B.C.; Polmear, I.J. Precipitate stability in Al-Cu-Mg-Ag alloys aged at high temperatures. Acta Metal. Mater. 1994, 42, 1715-1725. [CrossRef] 